\title{
EDUCATION GAME AS AN EFFORT DELIGHTFUL LEARNING IN THE ELEMENTARY SCHOOL
}

\author{
Zainal Abidin ${ }^{1}$, Nasrul ${ }^{1}$, Sri Amerta ${ }^{1}$, Vini Ariani Erwin ${ }^{1}$, Rahmawati Erwin ${ }^{1}$, Chandra ${ }^{1}$, \\ Yesi Anita $^{1}$, Annisa Kharisma ${ }^{1}$ \\ ${ }^{1}$ Universitas Negeri Padang, Indonesia \\ zainalabidin@fip.unp.ac.id, nasrul@fip.unp.ac.id, sriamerta@fip.unp.ac.id, chandra@fip.unp.ac.id, yesianita@fip.unp.ac.id, \\ viniarianierwin@gmail.com,rahmawatierwin93@gmail.com, annisakharisma@upi.edu
}

\begin{abstract}
This study aims to develop a thematic learning media in the era of industrial revolution 4.0 by using educational games for elementary students that are valid, practical and effective. Thematic learning media using educational games is closely related to innovation and the use of technology following the demands of the industrial revolution 4.0 era to increase student's attractiveness in learning. Thematic media learning was the result of development by using adobe flash CS6 program. The contained of media was thematic learning that integrates of several subjects. The development model used was 4-D (define, design, develop, disseminate). The research data was obtained from the validity test (media validation sheet), practicality (student and teacher response questionnaire), and effectiveness (student learning activities and results). Data were analyzed descriptively. The results showed that the thematic learning media was valid (media content according to curriculum, attractive design and layout, ease of operation, easy to understand students' language, and clear presentation according to student characteristics), practical (clear contents and objectives, easy to read, attractive appearance, and student interest increases), and effective (can increase student activity and learning outcomes). Learning media using educational games can create a fun learning process
\end{abstract}

Keywords: thematic learning media, era of industrial revolution 4.0, educational games, elementary schools.

\section{PENDIDIKAN GAME SEBAGAI UPAYA BELAJAR YANG MENYENANGKAN DI SEKOLAH DASAR}

\begin{abstract}
ABSTRAK
Penelitian ini bertujuan mengembangkan media pembelajaran tematik di era revolusi industri 4.0 dengan menggunakan game edukasi untuk siswa sekolah dasar yang valid, praktis, dan efektif. Media pembelajaran tematik menggunakan games edukasi ini berkaitan erat dengan inovasi dan pemanfaatan teknologi sesuai dengan tuntutan era revolusi industri 4.0 guna meningkatkan daya tarik siswa dalam pembelajaran. Media yang dikembangkan merupakan hasil kerja menggunakan bantuan program adobe flash CS6. Materi yang terdapat di dalam media adalah pembelajaran tematik yang mengintegrasikan beberapa mata pelajaran. Jenis penelitian pengembangan yang digunakan adalah Research and Development (R \& D) dengan model penelitian pengembangan 4-D (define, design, develop, disseminate). Data penelitian ini diperoleh dari uji validitas (lembar validasi media), praktikalitas (angket respon siswa dan guru), serta efektivitas (aktivitas dan hasil belajar siswa). Data dianalisis secara deskriptif. Hasil penelitian menunjukkan bahwa media pembelajaran tematik telah valid (isi media sesuai kurikulum, desain dan layout menarik, kemudahan pengoperasian, bahasa mudah dipahami siswa, serta penyajian jelas sesuai karakteristik siswa), praktis (isi dan tujuan yang jelas, mudah dibaca, tampilan menarik, dan minat siswa meningkat), serta efektif (dapat meningkatkan aktivitas dan hasil belajar siswa). Media pembelajaran dengan menggunakan game edukasi dapat menciptakan proses pembelajaran yang menyenangkan
\end{abstract}

Kata Kunci: media pembelajaran tematik, era revolusi industri 4.0, game edukasi, sekolah dasar.

\begin{tabular}{|c|c|c|}
\hline Submitted & Accepted & Published \\
\hline 12 Desember 2019 & 09 Januari 2020 & 28 Januari 2020 \\
\hline
\end{tabular}

\begin{tabular}{|l|c|c|}
\hline Citation & $:$ & $\begin{array}{r}\text { Abidin, Z., Nasrul, Amerta, S, Erwin, V.A., Erwin, R., Chandra., Anita, Y., \& Kharisma, A. (2020). Education Game As } \\
\text { An Effort Delightful Learning In The Elementary School. Jurnal PAJAR (Pendidikan dan Pengajaran), 4(1), } \\
122-135 . \text { DOI : http://dx.doi.org/10.33578/pjr.v4i1.7926. }\end{array}$ \\
\hline
\end{tabular}

\section{PENDAHULUAN}

Seiring perkembangan teknologi yang sangat pesat telah mengubah model, pola dan media pembelajaran di dunia pendidikan (Gutiérrez \& Jurow, 2016; Moodley, 2019;
Rienties, Tempelaar, \& Rienties, 2017). Pembelajaran dengan pemanfaatan teknologi seperti media audio, audiovisual, atau software komputer merupakan peluang yang 
memungkinkan terjadinya proses peningkatan mutu pembelajaran di dunia pendidikan baik secara kuantitas maupun kualitas (Baltaoğlu, 2019; Horn, 2018; Thadani et al., 2017; Turner et al., 2017). Perkembangan teknologi berpengaruh dalam bidang pendidikan, yaitu dengan semakin membantu ditemukannya metode pembelajaran baru dan pemanfaatan media berbasis komputer (Costa, Sousa, Rogado, \& Henriques, 2017; Garira \& Howie, 2019; Moffat, Crombie, \& Shabalina, 2017; Nadolny, Nation, \& Fox, 2019). Bahkan, kehadiran komputer dalam pendidikan telah menjadi awal yang baik bagi guru karena akan lebih mudah untuk membantu siswa menemukan pengetahuan baru dan proses pembelajaran lebih menyenangkan (Baltaoğlu, 2019; Costa et al., 2017; Garira \& Howie, 2019; Mclaren et al., 2017; Moodley, 2019).

Pemanfaatan teknologi ini dapat dilakukan dengan mengkombinasikan pembelajaran dan teknologi, salah satunya adalah melalui media (Gutiérrez \& Jurow, 2016; Rienties et al., 2017; Turner et al., 2017). Penggunaan media pembelajaran di era revolusi industri 4.0 masih kurang inovatif dan kurang tepat guna (Hendrizal \& Chandra, 2018; Horn, 2018; Levine, 2018; Lim, Lee, \& Ke, 2017; Taufina \& Chandra, 2018). Rendahnya variatif penggunaan media pembelajaran tematik disebabkan monoton dalam menggunakan buku kurikulum 2013. Hal ini menandakan rendahnya kemampuan kognitif siswa dalam proses pembelajaran (Alexander, 2019; Arnab, Morini, Green, Masters, \& Bellamy-Woods, 2017; Stewart, Hagood, \& Ching, 2017). Proses pembelajaran akan lebih efektif dan efisien dengan pemanfaatan komputer sebagai media pembelajaran (Costa, Tyner, Henriques, \& Sousa, 2018).

Pada usia SD, siswa cenderung lebih tertarik dengan media yang di dalamnya terdapat warna-warna cerah, animasi, serta permainan sehingga akan lebih mudah diingat (Grey, Grey, Gordon, \& Purdy, 2017; Jančič \& Hus, 2018; Miller et al., 2019). Permasalahan yang ditemui terkait media pembelajaran yang digunakan guru masih kurang inovatif dan kurang tepat guna dalam proses pembelajaran di era revolusi industri 4.0. Hal ini cenderung mengakibatkan suasana pembelajaran menjadi kurang menarik bagi siswa. Dalam dunia pendidikan sudah banyak aplikasi multimedia pembelajaran baik untuk anak-anak maupun orang dewasa baik itu dalam bentuk aplikasi ataupun game edukasi (Moffat et al., 2017; Nadolny et al., 2019; Urun, Aksoy, \& Comez, 2017).

Permasalahan dilapangan, kurangnya pemanfaatan media diakibatkan oleh beberapa hal, yaitu (1) pembelajaran didominasi menggunakan buku paket yang dirasa mencukupi kebutuhan pembelajaran di kelas; (2) buku paket yang digunakan kurang dilengkapi dengan informasi pendukung yang jelas; (3) buku paket yang digunakan sebagai media kurang menggambarkan bentuk aslinya. Hal tersebut sesuai dengan permasalahan yang ditemukan di lapangan.

Berdasarkan observasi yang dilakukan pada bulan Agustus 2018 pada kelas V SD. Pembelajaran tematik terpadu yang diterapkan pada kurikulum 2013 masih belum mempersiapkan siswa agar memiliki keterampilan era revolusi industri 4.0. Hal ini terlihat, pada penggunaan media yang digunakan. Media yang digunakan pada umumnya menggunakan media gambar dan media cetak dan jikalau menggunakan komputer hanya berupa slide powerpoint saja. Guru belum memiliki motivasi dan keterampilan untuk mengembangkan media yang lebih menarik sehingga dapat membuat siswa menjadi senang dan merasa pembelajaran tidak membosankan.

Saat observasi pada pembelajaran tematik terlihat bahwa media yang digunakan masih media gambar. Proses pembelajaran jarang dimodifikasi dalam bentuk permainan, padahal permainan sering dilakukan siswa dalam kesehariannya. Pembelajaran yang diciptakan terkesan kurang bermakna, menarik, dan menyenangkan. Belum menggunakan media pembelajaran yang efektif untuk membantu siswa memahami konsep-konsep dalam pembelajaran. Berdasarkan hasil pengamatan tersebut dapat dipahami bahwa minat dan motivasi siswa kelas V SD dalam pembelajaran tematik masih rendah.

Dapat disimpulkan bahwa media pembelajaran berperan penting dalam menyampaikan materi dan perlu dioptimalkan. 
Harus diciptakan media yang kreatif dan inovatif untuk menyampaikan materi pembelajaran sehingga tujuan pembelajaran tercapai dan berdampak positif terhadap hasil belajar siswa. Setelah mengamati pembelajaran dapat dipahami, salah satu faktor rendahnya hasil belajar dan kurangnya ketertarikan siswa dalam proses pembelajaran adalah media. Media pembelajaran merupakan salah satu pendukung proses pembelajaran (Moseley, 2018; Sawyer, 2017; Thadani et al., 2017). Faktor kurang ketertarikan inilah yang menyebabkan siswa kesulitan memahami materi pembelajaran yang disampaikan (Costa et al., 2017; Gholizadeh, Taghiyareh, \& Alvandkoohi, 2018; Remmele, 2017).

\section{KAJIAN TEORETIS}

Menurut teori Piaget bahwa anak umur 7/8 tahun - 11/12 tahun berdasarkan tingkat perkembangannya berada pada tahap operasional konkret (Callies, Gravel, Beaudry, \& Basque, 2017; Dunbar et al., 2017; Ibrahim, 2018). Pada tahap ini anak telah memiliki kecakapan berfikir logis, akan tetapi hanya dengan benda-benda yang bersifat konkret (Callies et al., 2017; Lim et al., 2017; Yilmaz \& Bayraktar, 2018). Anak pada umur tersebut berada pada jenjang pendidikan SD (Dang, Ved, \& Vemuri, 2018; Wilson et al., 2017). Oleh karena itu, seorang guru masih dapat menggunakan media pembelajaran namun harus dilakukan inovasi agar lebih menarik dan terlihat seakan konkret bagi siswa games (Grey et al., 2017; Javaid, 2017; Sardone, 2018). Penggunakan media pembelajaran dengan memanfaatkan teknologi diharapkan akan adanya perubahan suasana belajar menjadi lebih bervariasi dan aktif (Barclay \& Bowers, 2018; York \& DeHaan, 2018). Selain itu diharapkan juga akan berpengaruh terhadap minat belajar dan pemahaman siswa dalam menerima materimateri yang disampaikan oleh guru (Cardinot \& Fairfield, 2019; Jackson, 2017; Zielinski, 2019).

Menggunakan pengkodean merupakan keterampilan yang dapat bertahan lama, sangat berguna dalam kehidupan seorang anak (An \& Cao, 2017; Javaid, 2017; Jennett et al., 2017; Lui
Pada media pembelajaran tematik menggunakan game edukasi ini diharapkan dapat membantu siswa memahami materi tentang pembelajaran dengan mengamati gambar, materi dan game edukasi yang di proyeksikan melalui media. Secara tidak langsung siswa akan merasa terbantu dan lebih cepat memahami materi pembelajaran. Berdasarkan hal tersebut, penelitian ini digunakan untuk menghasilkan media pembelajaran tematik era revolusi industri 4.0 menggunakan game edukasi di sekolah dasar yang diharapkan mampu meningkatkan minat, motivasi dan daya tarik siswa dalam pembelajaran.

\& $\mathrm{Au}, 2018)$. Jadi penggunaan pengkodean berupa simbol akan mampu memudahkan pemahaman siswa. Penggunaan media ini juga dapat dijadikan sebagai penyalur kegemaran siswa dalam mengikuti perkembangan teknologi (Jackson, 2017; Kiili, Ojansuu, Lindstedt, \& Ninaus, 2018; Viswanathan \& Radhakrishnan, 2018). Siswa diharapkan melek teknologi dan bijak dalam penggunaannya.

Salah satu jenis media pembelajaran yang dapat digunakan adalah dengan menggunakan game edukasi. Media pembelajaran menggunakan game edukasi adalah suatu media yang dikemas dan didesain semenarik mungkin, dilengkapi dengan alat pengontrol yang dapat dioperasikan oleh pengguna, sehingga pengguna dapat memilih apa yang dikehendaki. Selain itu juga terdapat beberapa permainan yang dapat membantu siswa dalam memahami pembelajaran. Pembelajaran menggunakan media game edukasi ini bertujuan untuk memudahkan proses pembelajaran, menumbuhkan kekreatifan dan inovasi pendidik dalam mendesain pembelajaran yang komunikatif dan interaktif, serta sebagai solusi menghadapi permasalahan di tengah kesibukan pendidikan (An \& Cao, 2017; Costa et al., 2017; Gholizadeh et al., 2018; Mclaren et al., 2017; Miller et al., 2019; Moffat et al., 2017; Wilson et al., 2017; Yong et al., 2019) 


\section{METODE PENELITIAN}

Jenis penelitian ini adalah penelitian dan pengembangan atau Research and Development $(\mathrm{R} \& \mathrm{D})$. Model pengembangan yang digunakan mengacu pada model 4-D, yang dikemukakan oleh S. Thiagarajan, Dorothy S. Semmel, dan Melvyn I. Semmel. Menurut Thiagarajan, dkk. model ini terdiri dari empat tahap yaitu pendefenisian (define), perancangan (design), pengembangan (develop), dan penyebaran (disseminate).

Tahap uji coba penelitian ini dilaksanakan di kelas V SDN 02 Taluak, Kecamatan Lintau Buo, Kabupaten Tanah Datar. Tahap penyebaran dilakukan di kelas V SDN 03 Tigo Jangko, Kecamatan Lintau Buo, Kabupaten Tanah Datar.

Subjek penelitian pengembangan ini dilakukan pada siswa kelas V SD 2019 di SDN 02 Taluak, Kecamatan Lintau Buo, Kabupaten Tanah Datar sebanyak 24 orang siswa. Tahap penyebaran dilakukan pada SDN 03 Tigo Jangko, Kecamatan Lintau Buo, Kabupaten Tanah Datar 22 orang siswa.

Pengembangan media ini menggunakan langkah 4-D, yaitu (1) tahap pendefenisian (define), dengan melakukan analisis kurikulum dan analisis siswa, (2) tahap perancangan (design), dengan menentukan SK, KD, indikator, tujuan, dan materi pokok pembelajaran, mendesain dan merancang media terkait materi yang terdapat pada tema 1 subtema 2, (3) tahap pengembangan (develop), yaitu dengan melakukan uji validitas media kepada ahli (validator), uji praktikalitas media berupa angket kepada siswa kelas V SDN 02 Taluak, dan uji efektifitas media melalui kegiatan evaluasi yang diberikan kepada siswa untuk melihat apakah media yang dikembangkan mampu meningkatkan aktivitas dan hasil belajar siswa, (4) tahap penyebaran (disseminate), dilakukan pembatasan (karena keterbatasan waktu, tenaga dan biaya, sehingga penyebaran hanya dilakukan pada skala terbatas yaitu pada satu sekolah lain) penyebaran di kelas V SDN 03 Tigo Jangko.

Teknik analisis data yang digunakan adalah deskriptif kualitatif bertujuan menjelaskan produk media pembelajaran yang dikembangkan dan deskriptif kuantitatif terkait kelayakan produk yang diimplementasikan dalam pembelajaran. Langkahnya, pertama, untuk data deskriptif kuantitatif melakukan analisis validitas media menggunakan skala likert, dianalisis dalam skala (0-100) menggunakan rumus Nilai Validitas $=\frac{\text { Perolehan Skor }}{\text { Skor Maksimum }} \times 100 \%$ dengan kriteria (dalam persen): 0-20 (sangat tidak valid), 21-40 (tidak valid), 41-60 (kurang valid), 61-80 (valid), 81-100 (sangat valid).

Kedua, untuk deskriptif kuantitatif menggunakan analisis praktikalitas media melalui angket respon guru dan respon siswa berupa skala likert, dengan pengisian angket dilakukan menggunakan alternatif jawaban: 5 (sangat setuju-SS), 4 (setuju-S), 3 (kurang setujuKS), 2 (tidak setuju -TS), 1 (sangat tidak setujuSTS). Angket praktikalitas dideskripsikan dengan teknik analisis:

$$
\text { Praktikalitas }=\frac{\text { Skor yang diperoleh }}{\text { Skor maksimum }} \times 100 \%
$$

dengan kategori (dalam persen): 85-100 (sangat praktis), 75-84 (praktis), 60-74 (cukup praktis), 55-59 (kurang praktis), 0-54 (tidak praktis).

Ketiga, untuk deskriptif kuantitatif melakukan analisis efektivitas media meliputi: (a) analisis hasil pengamatan aktivitas siswa dengan kriteria (dalam persen): 81-100 (sangat tinggi/sangat efektif), 61-80 (tinggi/efektif), 4160 (sedang/cukup efektif), 21-40 (rendah/tidak efektif), 1-20 (sangat rendah/sangat tidak efektif), (b) analisis hasil belajar siswa dengan rumus $\mathrm{N}=\frac{\text { jumlah skor yang diperoleh }}{\text { jumlah skor maksimal }} 100 \%$. Data hasil belajar dibandingkan dengan kriteria ketuntasan minimal (KKM) yaitu 78. Sedangkan untuk deskriptif kualitatif melakukan pendeskripsian data hasil temuan pada data deskriptif kuantitatif. 


\section{HASIL DAN PEMBAHASAN}

Tahap Define (Pendefinisian)

Tahap define berkaitan dengan standar kompetensi, kompetensi dasar dan indikator yang ingin dicapai oleh peserta didik. Pada tahap ini peneliti melakukan beberapa langkah Pertama, analisis kurikulum, kegiatan analisis kurikulum berkaitan dengan analisis kompetensi inti (KI), kompetensi dasar (KD), indikator, tujuan, serta materi pembelajaran. Materi pembelajaran yang penulis kembangkan adalah materi pembelajaran yang terkait pada tema 1 subtema 2, manusia dan lingkungan. Pada subtema ini terdapat lima mata pelajaran; Bahasa Indonesia, IPA,IPS,PPKn dan SBdP. Kedua, analisis siswa, sebagian besar siswa cenderung tidak aktif dan kurang termotivasi serta sering bosan dan jenuh terhadap proses pembelajaran yang dilakukan guru. Penggunaan multimedia interaktif dapat mendorong siswa untuk belajar secara mandiri serta melayani kegiatan belajar sesuai kecepatan belajar masing-masing siswa. Bagi siswa yang relatif lambat dalam memahami materi pembelajaran dapat mengulangi pembelajaran sesuai keinginan siswa baik di sekolah maupun di luar sekolah.

Tahap Design (Perancangan)

Terdiri dari beberapa langkah. Pertama, rencana pelaksanaan pembelajaran (RPP), pembelajaran dirancang dengan menggunakan media menggunakan game edukasi. Kedua, media pembelajaran, langkahnya yaitu: Flowchart, (penggambaran secara fisik dari langkah-langkah dan urut-urutan prosedur dari suatu program); Story Board (sketsa gambar yang disusun berurutan sesuai naskah.

Langkah-langkah: (1) Buka aplikasi Adobe Flash CS. (2) Pilih Action Script 2.0 untuk membuka halaman kerja baru. (3) Setelah memilih menu Action Script 2.0 akan muncul halaman kerja dan sesuaikan dengan dimensi yang di inginkan. (4) Ganti nama Layer1 menjadi background untuk memudahkan pengeditan (apabila jumlah layer yang digunakan banyak) dengan klik kiri dua kali pada mouse tepat di teks Layer1.

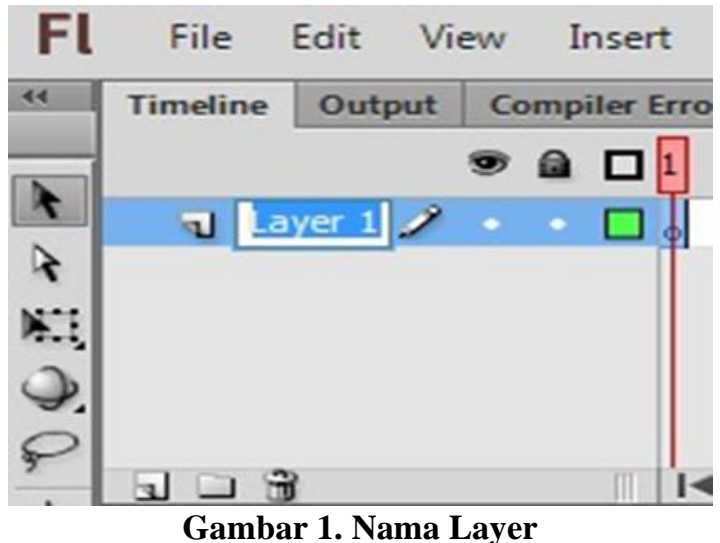

(5) Setelahhalaman kerja dan nama layer disesuaikan, untuk mengubah latar atau baground dengan meng-import file yang sudah disiapkan dengan cara pilih menu file, pilih import dan pilih
Import to Stage. (6) Buka jendela library dengan menekan Ctrl + L. Lalu klik and drag file gambar (Background.jpg) yang ada disana kedalam stage. 


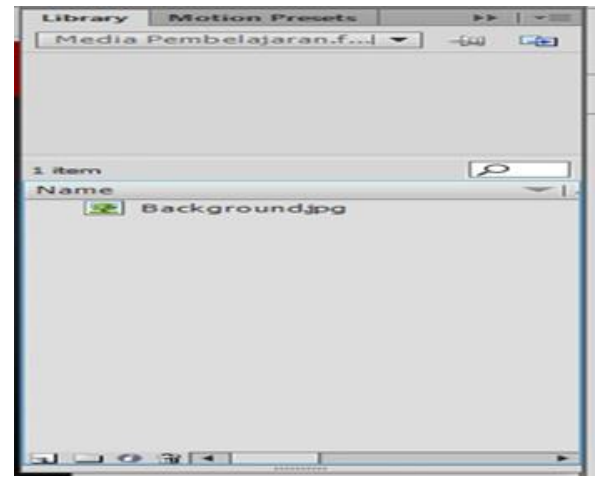

Gambar 2. Jendela Library

(7) Buka jendela Align untuk mengatur posisi image. Tekan $\mathrm{Ctrl}+\mathrm{K}$ untuk membuka jendela Align dan centang pada pilihan Align to stage, lalu klik center pada bagian Align dan Distribute. Bila benar maka file image (Background.jpg) akan berada di tengah stag

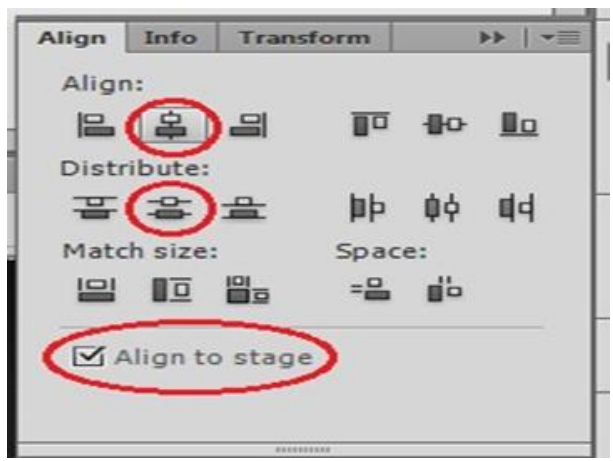

Gambar 3. Jendela Align

(8) Kunci layer background untuk tidak terganggu atau berubah posisi menjaga semua file yang ada pada layer tersebut

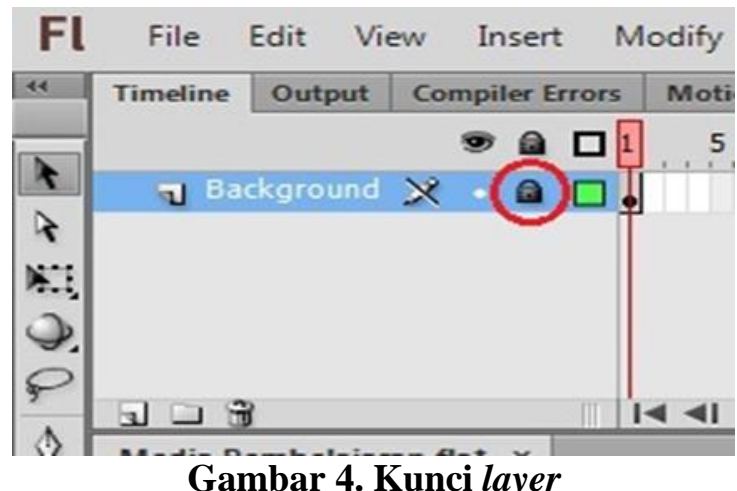

Gambar 4. Kunci layer 
(9) Tambahkan layer baru pada timeline icon New Layer pada panel timeline dengan cara klik insert/ timeline/ layer, atau klik

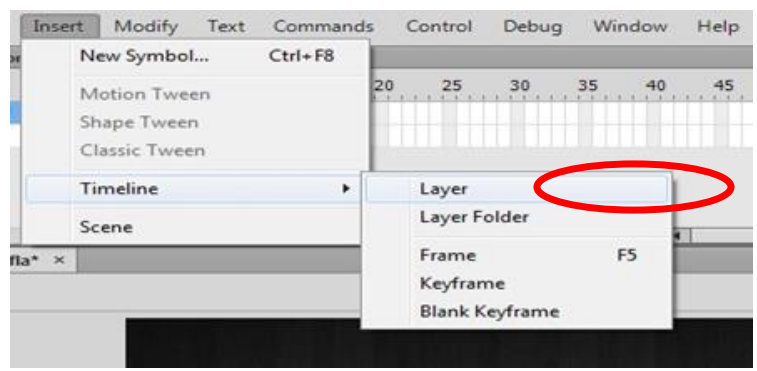

Gambar 5. New Layer

(10) Ganti nama layer menjadi tombol. Import file tombol yang sudah disiapkan seperti langkah 5 dan 6.

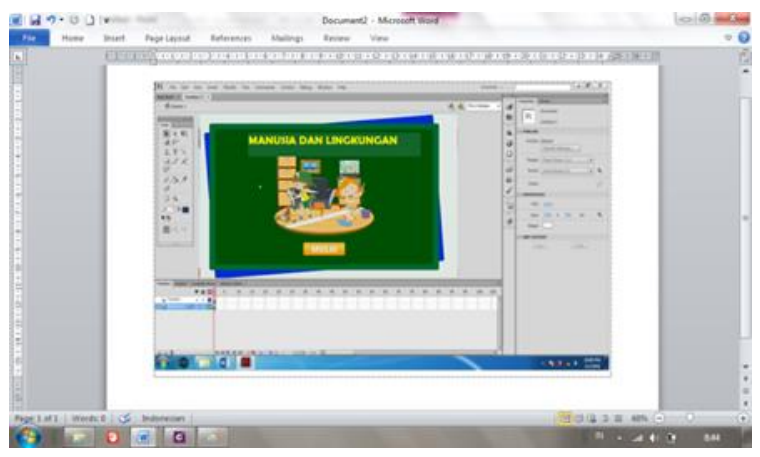

Gambar 6. Tombol telah di Import

(11) Lanjut untuk halaman media yang berikutnya. Untuk baground dan tombol tadi berada pada timeline ke 1, untuk halaman media berikutnya klik kanan pada layer baground pada timeline ke 2 lalu pilih insert keyframe. Begitu juga pada layer tombol. (12) Import semua bahan yang sudah di siapkan, tambahkan layer baru untuk lebih memudahkan dalam pengerjaan media. Lalu di susun sesuai keinginan. (13) Setelah semua bahan telah di import dan disusun, selanjutnya memberi script/ perintah pada setiap tombol agar berfungsi sesuai keinginan. (14) Klik control pada menu bagian atas lalu pilih test movie lalu pilih test, atau dengan cara cepatnya dengan menekan ctrl + enter pada keyboard. 


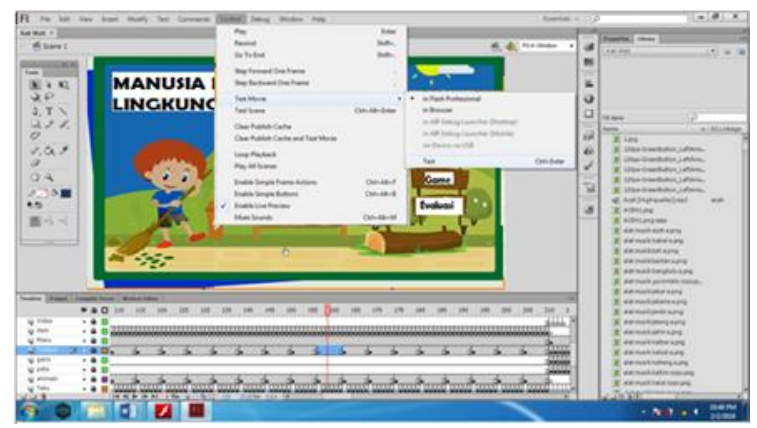

\section{Gambar 7. Tampilan untuk pengecekan dengan menjalankan media}

(15) Setelah itu akan muncul tampilan media yang sudah dikerjakan. (16) Setelah semuanya sudah berjalan sesuai keinginan, simpan media dengan pilih menu file, lalu pilih save as. (17) Setelah itu muncul sebuah tampilan yang disana akan terlihat dimana lokasi penyimpanan, nama file yang akan disimpan dan format penyimpanannya. Pilih format Flash CS6 Document $(*$ fla) agar suatu saat bias untuk diedit kembali.

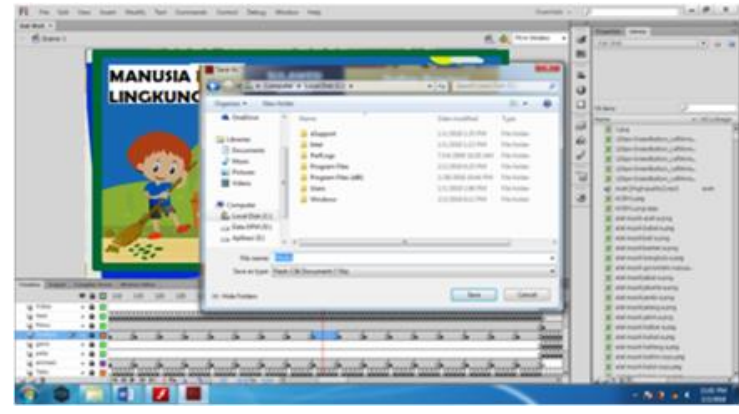

Gambar 8. Menyimpan file media

(18) Setelah disimpan, untuk media dapat dijalankan tanpa aplikasi membuatnya media harus di publish dengan cara pilih file lalu pilih publish setting. (19) Setelah itu muncul sebuah tampilan memilih format dalam bentuk apa media ini akan di jalankan. Cetang bagian Flash (.swf), html wrapper dan win projector. Pada hasil publish win projector file akan terpublish dan bentuk aplikasi (.exe). Tekan publish dan tunggu beberapa saat hingga proses publish selesai lalu klik OK.

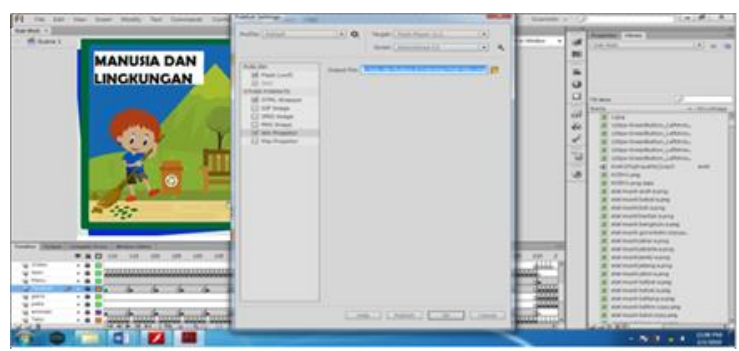

Gambar 9. Proses dan pemilihan format mempublish

(20) Buka lokasi penyimpanan dan publish, media sudah siap untuk dijalankan. 


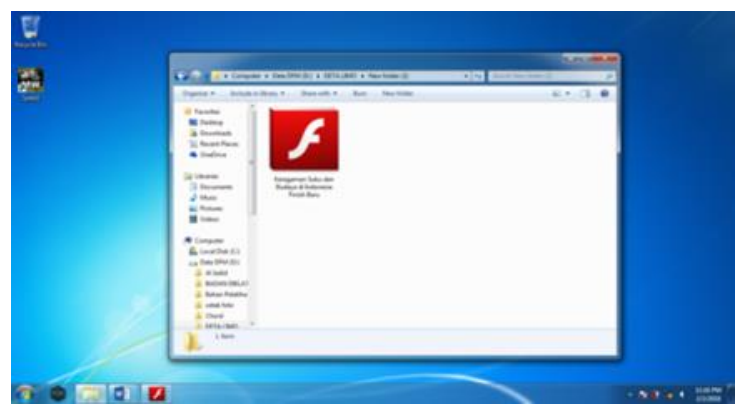

Gambar 10. File dalam format aplikasi (.exe) siap untuk dijalankan

\section{Tahap Develop (Pengembangan)}

Tahap pengembangan media pembelajaran meliputi validasi RPP dan validasi media pembelajaran, selanjutnya dilakukan revisi sesuai dengan saran. Penilaian Instrumen yang dilakukan terdiri dari instrumen validasi RPP, Media, Keterlaksanaan RPP, praktikalitas respon guru dan siswa terhadap media pembelajaran. Berdasarkan hasil validasi dapat diketahui bahwa instrumen pengumpulan data telah dinyatakan sangat valid dengan rata-rata $85.7 \%$.

\section{Validasi}

Terdiri dari: (1) Validasi RPP, dilakukan dengan tiga orang validator ahli dan dua orang validator praktisi. Rekapitulasi hasil validasi RPP bahwa rata-rata validasi RPP oleh ahli adalah $88.1 \%$ dan praktisi $91.7 \%$, sehingga dapat diperoleh rata-rata hasil validasi RPP adalah 89.9\% dengan kategori sangat valid; (2) Validasi Media, Hasil validasi media dari media aspek kesesuaian media, desain dan layout serta kemudahan dalam pengoperasian diperoleh hasil:

Tabel 1. Hasil Validasi Media

\begin{tabular}{ccc}
\hline Aspek Penilaian & Penilaian & Kategori \\
\hline Bahasa & $89.6 \%$ & Sangat Valid \\
Materi/ Isi & $94.7 \%$ & Sangat Valid \\
Media & $91.2 \%$ & Sangat Valid \\
\hline Jumlah & 275.5 & \\
\hline Rata-rata & $91.8 \%$ & Sangat Valid \\
\hline
\end{tabular}

Berdasarkan tabel di atas dapat dilihat rata-rata secara keseluruhan hasil validasi media pembelajaran berbasis multimedia interaktif adalah $91.8 \%$ yang termasuk kategori sangat valid. Hal ini menunjukkan bahwa keempat aspek, yaitu: media, isi/ materi, dan bahasa telah disusun secara lengkap dan sesuai dengan kebutuhan siswa dalam pembelajaran.

\section{Praktikalitas}

Uji coba media pembelajaran tematik menggunakan game edukasi dilakukan di SDN 02
Taluk. Uji coba dilakukan dalam beberapa kali pertemuan. Selama uji coba diamati oleh observer. Observer memiliki tugas mengamati pelaksanaan pembelajaran dan mengamati aktivitas siswa selama menggunakan media pembelajaran tematik menggunakan game edukasi. Rata-rata hasil keterlaksanaan RPP berada pada kategori sangat praktis dengan $90.7 \%$. Rata-rata penilaian respon guru berada pada kategori sangat praktis dengan persentase $90 \%$. Respon siswa terhadap praktikalitas media pembelajaran berbasis 
multimedia interaktif adalah $90.2 \%$ dengan kategori sangat praktis.

\section{Efektivitas}

Hasil efektifitas: (1) Aktivitas Siswa, ratarata aktivitas siswa pada setiap pertemuan $90.7 \%$ dengan kategori sangat baik. Artinya bahwa pada aktivitas siswa pada setiap pertemuan sudah baik, siswa telah aktif dengan mengajukan beberapa pertanyaan, mendengarkan penjelasan guru dengan baik, memberikan pendapat, mengerjakan latihan yang terdapat pada multimedia interaktif sesuai dengan langkah-langkah; (2) Evaluasi, hasil rata-rata nilai hasil evaluasi IPS siswa adalah 87,2 setelah menggunakan media berbasis multimedia interaktif.

\section{Tahap Disseminate (Penyebaran)}

Tahap penyebaran dilakukan di kelas $\mathrm{V}$ SDN 03 Tigo Jangko dengan hasil pengamatan aktivitas siswa setiap pertemuan memiliki persentase rata-rata 91.5 dengan kategori sangat baik. Artinya pada setiap pertemuan, aktivitas siswa secara keseluruhan sudah sangat baik. Evaluasi hasil belajar siswa sekolah penyebaran diperoleh rata-rata 87.4 dengan kategori sangat baik. Melihat paparan tersebut, penggunakan media pembelajaran tematik menggunakan game edukasi telah berjalan dengan efektif. Dengan demikian dapat disimpulkan bahwa penggunaan media pembelajaran tematik menggunakan game edukasi dapat digunakan secara efektif di kelas $\mathrm{V}$ SD berdasarkan uji coba dan penyebaran yang dilakukan.

\section{Pembahasan}

Berbagai masalah yang timbul selama proses pembelajaran dapat diatasi apabila materi disajikan dalam bentuk yang menarik. Tampilan yang menarik dapat menimbulkan keingintahuan siswa terhadap apa yang ditampilkan. Penyajian yang menarik menimbulkan perasaan senang dan motivasi dalam diri siswa untuk belajar sehingga materi dapat tersampaikan dengan baik. Belajar akan efektif apabila dilakukan dalam suasana yang menyenangkan (An \& Cao, 2017; Javaid, 2017; Jennett et al., 2017; Lui \& Au, 2018).

Jika siswa telah belajar dengan senang, tentu materi pembelajaran yang disampaikan akan lebih mudah diserap oleh siswa (Barnard, 2017;
Gauthier \& Jenkinson, 2017; Kim, 2019; Sardone, 2018; Yong, Gates, \& Chan, 2019). Oleh karena itu penyajian materi pembelajaran menggunakan media pembelajaran yang menarik perlu dilakukan. Salah satunya adalah melalui media pembelajaran tematik menggunakan game edukasi untuk siswa kelas V SD. Media ini menggunakan model 4-D terdiri atas empat tahap yaitu Define, Design, Develop, dan Disseminate. Selanjutnya diterapkan dalam pembelajaran.

Pada tahap Develop (pengembangan) dilakukan ujicoba yang disebut dengan tahap praktikalitas. Praktikalitas berkaitan dengan kemudahan dalam penggunaan. Praktikalitas atau bersifa kepraktisan, artinya mudah dalam melaksanakannya, mudah pemeriksaannya, dan dilengkapi dengan petunjuk yang jelas sehingga memudahkan pengguna (Cardinot \& Fairfield, 2019; Jackson, 2017; Zielinski, 2019) menjelaskan bahwa. Melihat tingkat kepraktisan media tematik menggunakan game edukasi ini praktis atau tidak, perlu dilakukan uji coba pada siswa kelas V SD.

Praktikalitas yang diamati adalah tingkat keterlaksanaan RPP, angket respon guru dan siswa terhadap praktikalitas media pembelajaran. Pertama, hasil keterlaksanaan RPP menunjukkan bahwa pembelajaran telah sesuai dengan perencanaan yang dirancang. Hal ini terlihat dari data hasil pengamatan keterlaksanaan RPP menggunakan media tematik menggunakan game edukasi yang dikembangkan sangat praktis digunakan. Selama uji coba, tidak ditemukan kendala berarti oleh guru dalam melaksanakan proses pembelajaran walaupun sedikit kekurangan waktu dan fasilitas pendukung seperti laptop/notebook, namun dapat diatasi. Kedua, hasil analisis terhadap angket respon guru menunjukkan bahwa media tematik menggunakan game edukasi yang diterapkan sangat praktis digunakan dalam proses pembelajaran. Terlihat dari jawaban guru tentang media pembelajaran yang digunakan. Hasilnya, guru menyatakan bahwa media pembelajaran yang dikembangkan berbeda dengan media pembelajaran sebelumnya dan mudah digunakan dalam proses pembelajaran di kelas V SD. Ketiga, analisis terhadap angket respon siswa menunjukkan bahwa siswa merasa terbantu dan menjadi lebih mudah dalam 
memahami materi pembelajaran. Siswa merasa media pembelajaran yang dikembangkan menarik karna didesain dengan warna yang menarik, gambar dan video serta dilengkapi dengan musik. Hasil analisis respon siswa memperoleh nilai dengan kualifikai sangat praktis. Hal ini terlihat dari hasil respon siswa yang menyatakan bahwa media yang dikembangkan praktis digunakan dalam pembelajaran. Menurut siswa keterbacaan media pembelajaran jelas dan sangat membantu dalam pembelajaran IPS.

\section{SIMPULAN DAN REKOMENDASI}

Pengembangan media pembelajaran tematik menggunakan game edukasi di kelas $\mathrm{V}$ SD dinyatakan valid. Hal ini sesuai dengan hasil penilaian ahli tentang produk multimedia interaktif yang dikembangkan baik dari aspek media, isi/ materi, dan bahasa dinilai sangat valid dengan revisi ringan. Jumlah rata-rata dari validator media 91.2, validator isi sebesar 94.7 dan validator bahasa 89.6 dengan rata-rata 91.8 kategori sangat valid. Hasil uji praktikalitas menunjukkan bahwa produk media pembelajaran tematik menggunakan game edukasi dari segi kepraktisan, mulai dari kemudahan penggunaan, manfaat, tampilan dan waktu, berdasarkan pandangan guru maka diperoleh nilai 90 dengan kriteria sangat baik, dan diperoleh nilai 90.2 dengan kriteria sangat baik dari segi siswa. Uji coba efektivitas dilakukan di kelas V SDN 02 Taluk dengan hasil sebesar 1745 dengan rata-rata hasil belaja 87.2. Berdasarkan perbandingan nilai

\section{DAFTAR PUSTAKA}

Alexander, C. (2019). Using Gamification Strategies to Cultivate and Measure Professional Educator Dispositions. International Journal of Game-Based Learning, $\quad 9(1), \quad 15$. https://doi.org/10.4018/IJGBL.2019010102

An, Y., \& Cao, L. (2017). Examining the Characteristics of Digital Learning Games Designed by In-service Teachers. International Journal of Game-Based Learning, https://doi.org/10.4018/IJGBL.2017100104
Berdasarkan pengembangan media pembelajaran tematik tersebut dapat disimpulkan bahwa media merupakan salah satu faktor yang sangat berpengaruh terhadap minat dan motivasi siswa selama proses pembelajaran. Pembelajaran bertujuan untuk menyajikan informasi dalam bentuk yang menyenangkan, menarik, mudah dimengerti, dan jelas (Callies et al., 2017; Lim et al., 2017; Yilmaz \& Bayraktar, 2018). Oleh karena itu perlu selalu dilakukan inovasi terhadap media pembelajaran yang digunakan.

hasil belajar dengan nilai ujian tengah semester siswa, terlihat bahwa media pembelajaran tematik menggunakan game edukasi di kelas V SD dapat meningkatkan motivasi belajar dan membantu siswa memahami materi pembelajaran. Hasil penelitian menunjukkan bahwa media pembelajaran yang dihasilkan menggunakan game edukasi dapat membawa perubahan suasana belajar yang lebih efektif disebabkan iklim belajar yang menyenangkan.

Dari simpulan di atas dapat peneliti rekomendasikan bahwa untuk kedepannya, praktisi pendidikan menjadikan game edukasi sebagai salah satu media yang dapat diterapkan dalam proses pembelajaran. Selain itu, diharapkan dengan adanya media game edukasi dapat menjadi salah satu dasar dalam melakukan penelitian untuk pengembangan media pembelajaran berikutnya di sekolah dasar maupun di sekolah menengah.

Arnab, S., Morini, L., Green, K., Masters, A., \& Bellamy-Woods, T. (2017). We are the Game Changers: An Open Gaming Literacy Programme. International Journal of Game-Based Learning, 7(3). https://doi.org/10.4018/IJGBL.2017070105

Baltaoğlu, M. G. (2019). Relationship between self-efficacy, learning strategies, and learning styles of teacher candidates ( Anadolu University example ). South African Journal of Education, 39(2), 1-11. 
Barclay, P. A., \& Bowers, C. (2018). Associations of Subjective Immersion, Immersion Subfactors, and Learning Outcomes in the Revised Game Engagement Model. International Journal of Game-Based Learning, $\quad 8(1)$. https://doi.org/10.4018/IJGBL.2018010103

Barnard, D. (2017). Case Study 2: Using Games Based on Giant Dice and Time Restrictions to Enable Creativity When Teaching Artistic or Creative Subjects. International Journal of Game-Based Learning, 7(3), 25.

https://doi.org/10.4018/IJGBL.2017070109

Callies, S., Gravel, M., Beaudry, E., \& Basque, J. (2017). Logs Analysis of Adapted Pedagogical Scenarios Generated by a Simulation Serious Game Architecture. International Journal of Game-Based Learning, $\quad 7(2), \quad 2-5$. https://doi.org/10.4018/IJGBL.2017040101

Cardinot, A., \& Fairfield, J. A. (2019). GameBased Learning to Engage Students With Physics and Astronomy Using a Board Game. International Journal of GameBased Learning, 9(1), 16. https://doi.org/10.4018/IJGBL.2019010104

Costa, C., Sousa, C., Rogado, J., \& Henriques, S. (2017). Playing Digital Security: Youth Voices on their Digital Rights. International Journal of Game-Based Learning, $\quad 7(3)$, 11-14. https://doi.org/10.4018/IJGBL.2017070102

Costa, C., Tyner, K., Henriques, S., \& Sousa, C. (2018). Game Creation in Youth Media and Information Literacy Education. International Journal of Game-Based Learning, $\quad 8(2), \quad 2-5$. https://doi.org/10.4018/IJGBL.2018040101

Dang, S., Ved, A., \& Vemuri, K. (2018). Geography Map Knowledge Acquisition by Solving a Jigsaw Map Compared to SelfStudy: Investigating Game Based Learning. International Journal of Game-Based Learning, $\quad 8(2), \quad 2-5$. https://doi.org/10.4018/IJGBL.2018040107

Dunbar, N. E., Jensen, M. L., Miller, C. H., Bessarabova, E., Lee, Y.-H., Wilson, S. N., ... Schuetzler, R. M. (2017). Mitigation of Cognitive Bias with a Serious Game: Two
Experiments Testing Feedback Timing and Source. International Journal of GameBased Learning, 7(4). https://doi.org/10.4018/IJGBL.2017100105

Garira, E., \& Howie, S. (2019). An analysis of quality of education and its evaluation: A case of Zimbabwean primary schools. South African Journal of Education, 39(2), $1-9$.

Gauthier, A., \& Jenkinson, J. (2017). Serious Game Leverages Productive Negativity to Facilitate Conceptual Change in Undergraduate Molecular Biology: A Mixed-Methods Randomized Controlled Trial. International Journal of Game-Based Learning, $\quad 7(2), \quad 2-5$. https://doi.org/10.4018/IJGBL.2017040102

Gholizadeh, M., Taghiyareh, F., \& Alvandkoohi, S. (2018). Toward a Propensity-Oriented Player Typology in Educational Mobile Games. International Journal of GameBased Learning, 8(2), 2-5. https://doi.org/10.4018/IJGBL.2018040105

Grey, S., Grey, D., Gordon, N., \& Purdy, J. (2017). Using Formal Game Design Methods to Embed Learning Outcomes into Game Mechanics and Avoid Emergent Behaviour. International Journal of GameBased Learning, 7(3), 7-10. https://doi.org/10.4018/IJGBL.2017070106

Gutiérrez, K. D., \& Jurow, A. S. (2016). Social Design Experiments: Toward Equity by Design. Journal of the Learning Sciences. https://doi.org/10.1080/10508406.2016.120 4548

Hendrizal, \& Chandra. (2018). Preliminary Research Description In Developing Tematics Learning Materials by Using Character Building and Discovery Learning to Establish Children aged 6-9 Years. In International Conference of Early Childhood Education (ICECE 2017) (Vol. 169, pp. 95-101). Atlantis Press. Retrieved from https://www.atlantispress.com/proceedings/icece-17/25889741

Horn, M. S. (2018). Tangible Interaction and Cultural Forms: Supporting Learning in Informal Environments. Journal of the Learning $\quad$ Sciences, $\quad O(0)$. 
https://doi.org/10.1080/10508406.2018.146 8259

Ibrahim, K. (2018). Player-Game Interaction: An Ecological Analysis of Foreign Language Gameplay Activities. International Journal of Game-Based Learning, 8(1). https://doi.org/10.4018/IJGBL.2018010101

Jackson, D. (2017). Can Games Help Creative Writing Students to Collaborate on StoryWriting Tasks? International Journal of Game-Based Learning, 7(3). https://doi.org/10.4018/IJGBL.2017070104

Jančič, P., \& Hus, V. (2018). Teaching Social Studies With Games. International Journal of Game-Based Learning, 8(2), 8-11. https://doi.org/10.4018/IJGBL.2018040106

Javaid, O. (2017). Case Study 4: Using GameBased Learning for Induction. International Journal of Game-Based Learning, 7(3), 35.

https://doi.org/10.4018/IJGBL.2017070111

Jennett, C., Papadopoulou, S., Himmelstein, J., Vaugoux, A., Roger, V., \& Cox, A. L. (2017). Case Study 3: Students Experiences of Interdisciplinary Learning while Building Scientific Video Games. International Journal of Game-Based Learning, $\quad 7(3), \quad 2-5$. https://doi.org/10.4018/IJGBL.2017070110

Kiili, K., Ojansuu, K., Lindstedt, A., \& Ninaus, M. (2018). Exploring the Educational Potential of a Game-Based Math Competition. International Journal of Game-Based Learning, 8(2), 2-5. https://doi.org/10.4018/IJGBL.2018040102

Kim, S. (2019). Role-Playing Game for Training a Design Process of Startup Company Compensation Plan. International Journal of Game-Based Learning, 9(2), 15. https://doi.org/10.4018/IJGBL.2019040103

Levine, S. (2018). Using Everyday Language to Support Students in Constructing Thematic Interpretations. Journal of the Learning Sciences, $\quad 00(00), \quad 1-31$. https://doi.org/10.1080/10508406.2018.148 5023

Lim, T., Lee, S., \& Ke, F. (2017). Integrating Music into Math in a Virtual Reality Game: Learning Fractions. International Journal of Game-Based Learning, 7(1). https://doi.org/10.4018/IJGBL.2017010104

Lui, R. W. C., \& Au, C. H. (2018). Establishing an Educational Game Development Model: From the Experience of Teaching Search Engine Optimization. International Journal of Game-Based Learning, 8(1). https://doi.org/10.4018/IJGBL.2018010104

Mclaren, B. M., Adams, D. M., Dame, N., Mayer, R. E., Barbara, S., \& Forlizzi, J. (2017). A Computer-Based Game that Promotes Mathematics Learning More than a Conventional Approach. International Journal of Game-Based Learning, 7(1). https://doi.org/10.4018/IJGBL.2017010103

Miller, C. H., Dunbar, N. E., Jensen, M. L., Massey, Z. B., Lee, Y.-H., Nicholls, S. B., ... Wilson, S. N. (2019). Training Law Enforcement Officers to Identify Reliable Deception Cues With a Serious Digital Game. International Journal of GameBased Learning, 9(3). https://doi.org/10.4018/IJGBL.2019070101

Moffat, D. C., Crombie, W., \& Shabalina, O. (2017). Some Video Games Can Increase the Player ' $\mathrm{s}$ Creativity. International Journal of Game-Based Learning, 7(2), 25.

https://doi.org/10.4018/IJGBL.2017040103

Moodley, M. (2019). WhatsApp: Creating a virtual teacher community for supporting and monitoring after a professional development programme. South African Journal of Education, 39(2), 1-10.

Moseley, A. (2018). Real-Life Contexts in Learning Games: Towards a New Typology. International Journal of GameBased Learning, 8(4), 10-13. https://doi.org/10.4018/IJGBL.2018100102

Nadolny, L., Nation, J., \& Fox, J. (2019). Supporting Motivation and Effort Persistence in an Online Financial Literacy Course Through Game-Based Learning. International Journal of Game-Based Learning, $9(3)$. https://doi.org/10.4018/IJGBL.2019070103

Remmele, B. (2017). Playing Against the Game. International Journal of Game-Based Learning, $7(3)$. https://doi.org/10.4018/IJGBL.2017070107 
Rienties, B., Tempelaar, D., \& Rienties, B. (2017). Turning Groups Inside Out: A Social Network Perspective. Journal of the Learning Sciences, O0(00), 1-30. https://doi.org/10.1080/10508406.2017.139 8652

Sardone, N. B. (2018). Attitudes Toward Game Adoption: Preservice Teachers Consider Game- Based Teaching and Learning. International Journal of Game-Based Learning, $\quad 8(3)$, 10-13. https://doi.org/10.4018/IJGBL.2018070101

Sawyer, R. K. (2017). Teaching and Learning How to Create in Schools of Art and Design. Journal of the Learning Sciences, 8406(October).

https://doi.org/10.1080/10508406.2017.138 1963

Stewart, M. K., Hagood, D., \& Ching, C. C. (2017). Virtual Games and Real- World Communities: Environments that Constrain and Enable Physical Activity in Games for Health. International Journal of GameBased Learning, 7(1). https://doi.org/10.4018/IJGBL.2017010101

Taufina, \& Chandra. (2018). The Implication of Authentic Assessment in Thematic Integrated Learning Process at Lower Level Elementary School Early Childhood Development. In Social Science, Education and Humanities Research (Vol. 169, pp. 140-143). https://doi.org/10.2991/icece17.2018 .36

Thadani, V., Roth, K. J., Garnier, H. E., Seyarto, M. C., Thompson, J. L., Froidevaux, N. M., ... Seyarto, M. C. (2017). What Can a Cognitive Coding Framework Reveal about Professional Development's Effects on Classroom Teaching and Learning? Journal of the Learning Sciences, $0(0)$. https://doi.org/10.1080/10508406.2017.139 6220

Turner, J. C., Christensen, A., Kackar-cam, H. Z., Sara, M., Trucano, M., Turner, J. C., ... Christensen, A. (2017). The Development of Professional Learning Communities and Their Teacher Leaders: An Activity Systems Analysis. Journal of the Learning
Sciences, $\quad 00(00), \quad 1-40$. https://doi.org/10.1080/10508406.2017.138 1962

Urun, M. F., Aksoy, H., \& Comez, R. (2017). Supporting Foreign Language Vocabulary Learning Through Kinect-Based Gaming. International Journal of Game-Based Learning, $7(1)$. https://doi.org/10.4018/IJGBL.2017010102

Viswanathan, S., \& Radhakrishnan, B. (2018). A Novel ' Game Design' Methodology for STEM Program. International Journal of Game-Based Learning, 8(4). https://doi.org/10.4018/IJGBL.2018100101

Wilson, S. N., Engler, C. E., Black, J. E., YagerElorriaga, D. K., Thompson, W. M., McConnell, A., ... Terry, R. A. (2017). Game-Based Learning and Information Literacy: A Randomized Controlled Trial to Determine the Efficacy of Two Information Literacy Learning Experiences. International Journal of Game-Based Learning, $\quad$ 7(4). https://doi.org/10.4018/IJGBL.2017100101

Yilmaz, O., \& Bayraktar, D. M. (2018). Impact of Kinect Game on Primary School Students ' Mental Computation Speed. International Journal of Game-Based Learning, 8(4). https://doi.org/10.4018/IJGBL.2018100104

Yong, S. T., Gates, P., \& Chan, A. T.-Y. (2019). Similarities and Differences in Learning of Metacognitive Skills: Computer Games Versus Mathematics Education. International Journal of Game-Based Learning, $\quad 9(1), \quad 10-13$. https://doi.org/10.4018/IJGBL.2019010101

York, J., \& DeHaan, J. W. (2018). A Constructivist Approach to Game- Based Language Learning: Student Perceptions in a Beginner- Level EFL Context. International Journal of Game-Based Learning, $8(1)$. https://doi.org/10.4018/IJGBL.2018010102

Zielinski, D. (2019). Can Playing Games Help Students Master Concepts from General Psychology Classes? International Journal of Game-Based Learning, 9(2), 2-5. https://doi.org/10.4018/IJGBL.2019040104 